\title{
O Crédito
}

\section{Resumo}

O crédito é elemento de fundamental importância para o crescimento econômico de um país. Contudo, na história brasileira recente, por vezes, ele tem sido ressaltado, principalmente para o pequeno investidor, como um mal a ser evitado; uma armadilha capaz de levar à bancarrota pessoas e empresas. Na verdade, é preciso entender que a oferta de crédito e as condições para sua obtenção estão diretamente vinculadas à política monetária do governo e às perspectivas de crescimento econômico. Este artigo trata, brevemente, do significado do crédito, de sua importância para a sociedade e seu comportamento diante do ciclo econômico.

\section{Abstract}

The credit is an element of fundamental importance for a country' economic grow. Nevertheless, in Brazilian recent History, many times, it has been emphasized, principally for the small investor as a bad thing to be avoided, something able to cause damage to people and enterprises. Actually, it is necessary to understand that the offer of credit and the conditions for obtaining it are directly related to a Government monetary politics, and to the economic grow perspectives. This article tries to present, a brief conceptualization of credit, its importance to the society $e$ its behavior face the economic cycle.

\section{O crédito e sua importância}

A palavra crédito vem do latim e significa "crença, confiança". Assim, pode-se entender que ter crédito é desfrutar de confiança, de credibilidade.

Perera (1998:1) conceitua uma operação de crédito como a troca de um valor presente pela promessa de um pagamento futuro, que pode ser representada tanto pela cessão de prazo de pagamento de um fornecedor para seu cliente quanto por uma operação de empréstimo.

No âmbito específico das entidades bancárias, Silva (1997:63) entende que crédito consiste na disponibilização ao cliente de certo valor sob a forma de empréstimo ou financiamento, mediante uma promessa de devolvê-lo em montante maior numa data futura.

Dessas colocações depreende-se que o fator preponderante para viabilizar uma operação creditória é a crença no retorno do recurso emprestado e pode-se generalizar que dispor de crédito corresponde à capacidade de obter recursos, financeiros ou não, mediante a promessa de pagamento futuro, porque o credor tem confiança de que a promessa feita será cumprida e está disposto a conceder disponibilidades imediatas em troca de futuras, ou seja, abre mão de sua liquidez por um intervalo de tempo definido.

Em razão da característica de permitir às empresas e aos indivíduos o acesso à liquidez renunciada temporariamente por outros agentes integrantes do mercado, o crédito desempenha papel fundamental dentro de uma sociedade. Funciona como elemento de propulsão às transações econômicas na medida em que expande o poder de compra e investimento dos agentes econômicos para além de suas capacidades de autofinanciamento.

Do ponto de vista específico das empresas, o crédito representa uma fonte de capital para realização de seus projetos, a ser sempre considerada

\footnotetext{
* Mestre em Controladoria e Contabilidade pela FEA/USP. Professora dos cursos de Ciências Contábeis e Comércio Exterior das Faculdades Integradas "Campos Salles" e Faculdades Teresa Martin.
} 
quando da tomada de decisões de investimento e financiamento.

Assaf Neto (1997) salienta que essas decisões são integradas e estão presentes nas empresas de forma contínua e inevitável, independentemente da natureza de suas atividades. Para ele, as decisões de investimento envolvem todo o processo de identificação, avaliação e seleção das alternativas de aplicações de recursos, conforme identificadas nos ativos, preocupando-se com os retornos esperados. As decisões de financiamento, por seu lado, têm como foco a definição da natureza dos fundos a serem empregados na realização dos investimentos, tendo em vista o retorno exigido pelos detentores de capital.

A despeito de discussões ${ }^{1}$ sobre a existência de uma estrutura de capital ótima, ou seja, de uma composição ideal de fontes de financiamento (recursos próprios ou de terceiros) que permita o alcance dos melhores resultados econômicos, o crédito constitui-se numa opção, como fonte de recursos, para viabilizar a consecução de investimentos.

Caouette et al (1999:12) sugerem que as designações tomador e devedor, normalmente utilizadas para denominar o receptor dos recursos oriundos de uma operação de crédito, deveriam ser substituídas por alavancador. Para eles, as denominações tomador e devedor carregam uma conotação negativa às pessoas e entidades que se utilizam de recursos de terceiros, enquanto alavancagem denota os atributos de esperteza e habilidade aos seus usuários, por se utilizarem de uma ferramenta que multiplica sua força empreendedora.

Beckman apud Perera (1998:7) ratifica e enfatiza a importância do crédito e seu poder de alavancagem dentro do mundo dos negócios:

\section{(...) Os homens de negócio há muito reco-} nheceram que o crédito é um fator dinâmico e causal no mundo dos negócios. Ele aumenta o volume das vendas, abre mercados de novos compradores, facilita vendas, cria consumidores satisfeitos e cria demanda para alguns produtos, que não a teriam na ausência de crédito. Mais amplamente conceituado, o crédito pode ser visto como um estimulante $e$ mesmo fator causal também da economia como um todo. Economistas têm atribuído parcialmente ao crédito não somente a expansão da nossa economia, mas também parte de seu caráter cíclico. A nossa é uma economia de crédito como é evidenciado pelo nosso sistema bancário e outras instituições financeiras, nosso uso intensivo dos instrumentos de crédito e nossa quase universal atitude favorável ao crédito. Conseqüentemente, as políticas adotadas para contrair o crédito têm tido um efeito direto sobre inclinação e o volume da atividade negocial.

As políticas de contração citadas pelo autor referem-se às intervenções do governo na economia mediante o uso de instrumentos de política monetária que permitem, conforme Fortuna (1993:35), o controle de volumes, prazos, destinação e nível de preço do crédito, por meio da fixação de taxa básica de juros da economia, do estabelecimento de limites operacionais e condições de acesso etc. Esse conjunto de medidas representa restrições às forças naturais de mercado (demanda e oferta).

Essas interferências governamentais ocorrem justamente pelo reconhecimento do papel econômico e social desempenhado pelo crédito numa sociedade capitalista, visto que ele exerce forte influência sobre o nível de atividade produtiva por possibilitar o financiamento de novos investimentos, atender às necessidades de recursos temporários dos tomadores e permitir aos indivíduos a satisfação imediata de uma necessidade ou desejo de consumo a ser pago no futuro, gerando novas oportunidades e demandas por bens e serviços.

\footnotetext{
${ }^{1}$ Essas discussões dizem respeito à posição de Modigliani e Miller que defendem a inexistência de uma estrutura de capital ótima, sob determinadas condições, uma vez que o valor da empresa independe de sua estrutura de capital, enquanto autores como Zysman acreditam que a composição das fontes de financiamento afetam os resultados econômicos. De forma resumida, pode-se encontrar os argumentos sobre essas discussões nas obras de Ross et alii (1997), Zonenschain (1998) e Assaf Neto (1997).
} 
Com toda a certeza, a política monetária é um dos fatores com maior poder de influência sobre a disponibilidade e o acesso aos haveres financeiros em uma economia. O uso de mecanismos de controle creditório altera ou mantém a relação entre a demanda e oferta de recursos com vistas à retração ou expansão, em maior ou menor grau, do volume de empréstimos e financiamentos, e, por conseguinte, da atividade econômica. A definição dessa política está vinculada ao momento e à política econômica adotada pelos dirigentes na condução do desenvolvimento do país.

Não obstante as definições de política monetária, as entidades especializadas na oferta de crédito têm em seu modelo de gestão de risco de crédito a definição final das condições e preço com que os recursos são disponibilizados às empresas e ao público em geral, podendo reduzir ou aumentar as discriminações ${ }^{2}$ elencadas por Kanitz (1976:6-7) e que ainda se fazem presentes, onde, por vezes, são excluídos do crédito clientes com grande potencial de expansão. Como ressalta Silva (1999), ao dizer que o problema do crédito não é torná-lo mais fácil e mais ágil, mas consiste em facilitá-lo às pessoas que o merecem e fazer com que os maus pagadores arquem com o ônus de sua conduta ao obterem novos créditos.

Montoro Filho (1982:48) explana que o sistema financeiro é capaz de libertar parcialmente os investidores da necessidade de possuírem capital acumulado para realizarem investimentos e oferece maior flexibilidade de alteração de planos no presente e no futuro. Para ele, essa é a razão fundamental, para que exista uma dependência do volume de investimento agregado da economia às condições do mercado de crédito.

\section{Ciclo do crédito}

De acordo com o exposto na seção anterior, o crédito possui um estreito vínculo com as mudanças nos níveis de atividade econômica. Em condições normais, quanto maior o nível de atividade, maior será a demanda por crédito e, quanto maior a disponibilidade de crédito, maior o potencial de crescimento da economia.

Mueller (1997:47) caracteriza esse vínculo, ao propor o ciclo do crédito em conformidade com o ciclo econômico e estabelecer seus quatro estágios: surto de crescimento, explosão, recessão e recuperação.

O primeiro estágio, surto de crescimento, é caracterizado pelo autor por possuir alta utilização de mão-de-obra e capacidade instalada, em que normalmente produção de bens e serviços chega a exceder o potencial de crescimento da economia. Os recursos destinados ao crédito são abundantes e os credores tendem a tornar-se excessivamente agressivos na oferta de recursos, esquecendo-se muitas vezes de erros do passado e assumindo posições de risco baseados na situação de momento, onde a prosperidade mascara os erros.

Épocas favoráveis induzem à euforia e os agentes econômicos falham quando não consideram os sinais de problemas que se acumulam e tornam maior o risco de crédito. Segundo Mueller, grandes perdas com crédito estão associadas às operações contratadas nesse período.

O estágio de explosão está vinculado à ruptura do crescimento e ao desequilíbrio das forças de mercado. Há uma tendência à elevação do índice de inflação e de interferências do Banco Central na economia na tentativa de refrear a erosão do poder aquisitivo. À medida que a inflação se mantém, pode haver estagnação e redução das atividades econômicas decorrente da redução do poder de compra dos consumidores. Nesse estágio, os credores passam a manter uma postura defensiva, em virtude do impacto negativo desse cenário macroeconômico na qualidade do crédito.

\footnotetext{
${ }^{2}$ Essas discriminações dizem respeito àqueles tomadores que não possuem garantias ou histórico de crédito, como é o caso de empresas em fase de implantação ou de consultorias, bem como as empresas que possuem potencial de geração de resultados positivos, mas que se encontram circunstancialmente com dificuldades financeiras, sendo por vezes induzidas à falência pela recusa sistemática das instituições financeiras em ceder-lhes crédito.
} 
$\mathrm{Na}$ recessão, o cenário é de alto índice de desemprego e de capacidade ociosa. A produtividade e a competição entre as firmas crescem com o objetivo de reduzir custos e se manter no mercado. Os credores guardam posição de extrema cautela diante do quadro desfavorável à obtenção de bons resultados.

No estágio seguinte, recuperação, observa-se a aceleração nos gastos do consumidor, aumento no giro dos estoques e interesse em aquisições corporativas. O crescimento econômico e o excesso de liquidez trazem de volta a oferta de recursos. A competição por tomadores induz os outorgantes de crédito a realizarem operações com margens estreitas e maior nível de risco.
Com a retomada do crescimento potencial da economia, os credores reassumem com euforia novos negócios, mas intensificam testes sobre experiências passadas.

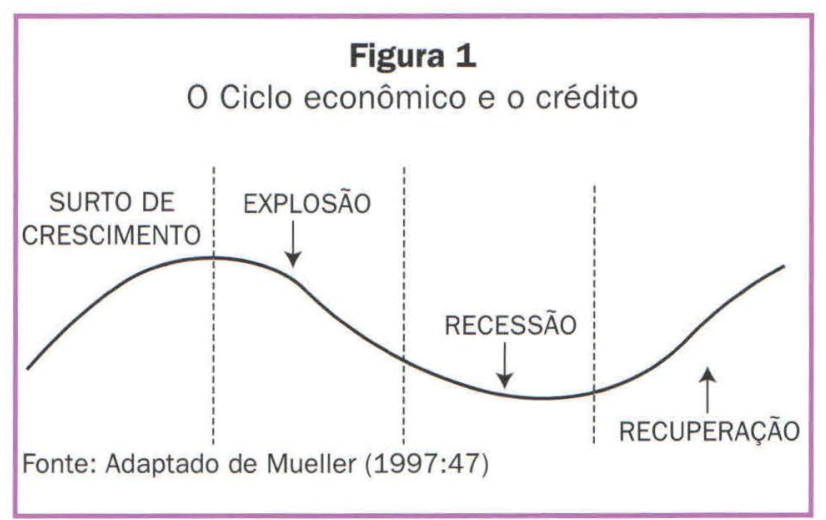

\section{REFERÊNCIAS BIBLIOGRÁFICAS}

ASSAF NETO, Alexandre. A dinâmica das decisões financeiras. Cadernos de Estudos. São Paulo. v.9. n. 16, p. 9-25, jul/dez. 1997.

CAOUETTE, John B. et al. Gestão do risco de crédito: o próximo grande desafio financeiro. Rio de Janeiro: Qualitymark, 1999. FORTUNA, Eduardo. Mercado financeiro: produtos e serviços. 2. ed. Rio de Janeiro: Qualitymark, 1993.

KANITZ, Stephen Charles. Indicadores contábeis e financeiros de previsão de insolvência: a experiência na pequena e média empresa brasileira. 1976. Tese (Livre docência). Faculdade de Economia e Administração, Universidade de São Paulo, São Paulo.

MONTORO FILHO, André Franco. Moeda e sistema financeiro no Brasil. Rio de Janeiro: IPEA/INPES, 1982.

MUELLER, P. Henry. Ciclos e cultura de crédito. Revista Tecnologia do Crédito. P. 45-57, nov/97.

PERERA, Luiz Carlos Jacob. Decisões de Crédito para grandes corporações. 1998. Tese (Doutorado). Faculdade de Economia e Administração, Universidade de São Paulo, São Paulo.

SILVA, José Pereira da. Gestão e análise de risco de crédito. São Paulo: Atlas, 1997.

Fórum Internacional de Crédito Serasa , 2. [s.1.], 1999. CD-Rom. 